В. В. Семенко ${ }^{1}$, В. М. Сердюк', І. В. Савицький ${ }^{2}$

${ }^{1}$ КЗ «Дніпропетровська обласна клінічна офтальмологічна лікарня» - м. Дніпро, Україна,

${ }^{2}$ Одеський національний медичний університет МОЗ України - м. Одеса, Україна

\title{
ПОРІВНЯЛЬНА ХАРАКТЕРИСТИКА СТРУКТУРНИХ ЗМІН ОЧНОГО ЯБЛУКА ПРИ ЕКСПЕРИМЕНТАЛЬНОМУ ЦУКРОВОМУ ДІАБЕТІ 1-го ТА 2-го ТИПІВ
}

\begin{abstract}
Діабетична ретинопатія - загрозливе ускладнення цукрового діабету. Мета роботи: проведення порівняльної характеристики змін очного яблука при експериментальній алоксановій моделі цукрового діабету 1-го та 2-го типу. Дослідження проведено на білих щурах лінії Вістар аутобрендного розведення, які були ранжовані на 3 групи. Виявлено односпрямовану тенденцію пошкодження структур очного яблука при відтворенні запропонованих алоксанових моделей експериментального цукрового діабету 1-го та 2-го типів.

Ключові слова: иукровий діабет, діабетична ретинопатія, експериментальна модель 1-го та 2-го типів, алоксан, гістологічне дослідження.
\end{abstract}

Діабетична ретинопатія (ДР) - загрозливе ускладнення цукрового діабету, яке призводить не лише до погіршення якості життя, а й до значної інвалідизації населення. Кількість пацієнтів, що страждають на дану патологію, невпинно збільшується. Зокрема відомо, що ДР діагностується у 50\% хворих на цукровий діабет (ЦД) 1-го типу при тривалості захворювання 10-15 років і у 75-90\% хворих при тривалості захворювання на діабет більше 15 років [3]. За прогнозами спеціалістів, у наступні 30 років на $27 \%$ зросте кількість випадків сліпоти і на 45\% - зниження зору серед пацієнтів, що страждають на ЦД [14, 15].

Враховуючи, що за даними ВООЗ кількість пацієнтів 3 цукровим діабетом зросла від 108 мільйонів у 1980 році до 422 мільйонів пацієнтів у 2014 році $[2,13]$ і за прогнозами Міжнародної діабетичної федерації до 2030 року становитиме більш ніж 550 мільйонів [6, 9], актуальність та подальше вдосконалення методів профілактики і корекції діабетичної ретинопатії не викликає сумнівів.

Відомо, що при ЦД спостерігається активізація процесів вільно радикального окиснення, яке призводить до структурного та функціонального порушення мембран $[5,7]$ та зниження відповіді ферментів антиоксидантного захисту, і є однією із значущих ланок розвитку та прогресу діабетичної ретинопатії. [4] . Важливим моментом у патогенезі діабетичної ретинопатії є розвиток окислювального стресу, пов'язаного з підвищеним утворенням вільних радикалів, які руйнівно впливають на сітківку ока [10]. Остання, у свою чергу, постійно підлягає впливу світла та кисню і є високочутливою до гіпоксичних станів і розвитку окислювального стресу [11].

Тому викликає науковий інтерес дослідження факторів, які впливають на баланс між про- та антиокси- дантною системою. Фізіологічно найбільш вдалою для вищезазначеного дослідження є використання алоксанової моделі цукрового діабету. Здебільшого ці моделі відтворювали цукровий діабет 1-го типу.

При цьому необхідним є дослідження доцільності використання алоксанової моделі для моделювання ЦД 2-го типу та спричиненої ним діабетичної ретинопатії 3 огляду на переважання захворюваності на Ц 2-го типу в порівнянні з кількістю хворих на ЏД 1-го типу.

Мета: проведення порівняльної характеристики змін очного яблука при експериментальній алоксановій моделі цукрового діабету 1-го та 2-го типу.

Матеріали та методи. Дослідження проведено на білих щурах лінії Вістар аутобрендного розведення масою 180-200 г. Відповідно до мети роботи тварини були ранжовані на 3 групи:

1-a група - 20 тварин, які не піддавалися ніякому впливу, слугували контролем;

2-a група - 30 тварин, у яких моделювали цукровий діабет 1-го типу;

3-я група - 30 тварин, у яких моделювали цукровий діабет 2-го типу.

ЦД 1-го типу моделювали триразовим внутрішньочеревним, $з$ інтервалом 5 днів, введенням алоксану в дозі 7,5 мл. Введення алоксану здійснювали на фоні вільного пиття тваринами 5\% розчину фруктози. Тривалість експерименту - 30 діб. Використання цієї моделі супроводжувалось 100\%-м виживанням піддослідних щурів.

ЦД 2-го типу моделювали за допомогою триразового введення алоксану у дозі 4 мг/100 г маси тварини. Введення алоксану здійснювали на фоні вільного пиття тваринами 10\%-го розчину фруктози. 
Тварин виводили 3 досліду шляхом декапітації під легким ефірним наркозом згідно 3 «Правилами виконання робіт з використанням експериментальних тварин», затверджених Наказом МОЗ України № 249 від 01.03.2012 та Законом України № 3447-IV «Про захист тварин від жорстокого поводження» (зі змінами від 15.12.2009 та від 16.10.2012). 3 одержаних після цього матеріалів проводили гістологічне дослідження підшлункової залози експериментальних тварин. Використовували фарбування за Маллорі та Ван Гізоном. Отримані препарати аналізували під світловим мікроскопом. Проводили енуклеацію. Очні яблука фіксували 24 години в 4\%-му розчині параформальдегіду, потім одержані матеріали проводили через спирти зростаючої концентрації і заливали у целоїдин за загальноприйнятою методикою. 3 отриманих блоків виготовляли гістологічні зрізи 7-9 мкм, які фарбували гематоксиліном-еозином. Отримані препарати досліджували під світловим мікроскопом і визначали структурні зміни в утвореннях очного яблука.

Результати та їх обговорення. Гістологічні дослідження підшлункової залози тварин контрольної групи показали, що в острівцях Лангерганса серед ендокриноцитів диференціюються $\alpha$ - та $\beta$-клітини. При цьому основну масу клітинного складу острівців підшлункової залози складають $\beta$-клітини (блакитна зернистість цитоплазми) (рис. 1).

При гістологічному дослідженні стінки очного яблука виявлено численні тонкостінні судини судинної оболонки, які місцями виглядають як лакуни. У сітчастій оболонці чітко проглядається шаруватість. Клітини гангліонарного шару з соковитими округлими ядрами розташовуються в один шар, рівномірно (рис. 2).

У гранулярних шарах клітини 3 темними округлими ядрами розташовуються щільними масивами. В пігментному шарі визначаються рівномірно розташовані темні гранули різних розмірів. Кришталик оточений однорідною щільною мембраною, на внутрішній поверхні якої визначаються розташовані в один ряд клітини з дрібними темними ядрами. Тіло кришталика безбарвне, однорідне.

Дослідження тварин, у яких моделювали цукровий діабет, показало наступне. Острівці Лангерганса довгуватої форми. Значно зменшена кількість ендокриноцитів. Останні з ознаками дистрофії: дегенеративно змінені ядра у вигляді гіперхроматозу, каріопікнозу, каріолізису (рис. 3).

Серед виявлених гістологічних змін очного яблука варто звернути увагу на таке: в судинному шарі хоріоідеї (В) визначається фіброзне стовщення стінки, набухання волокон, набухання і округлення ядер ендотелію, неупорядковане розміщення ендотеліоцитів (рис. 4).

У гангліонарному шарі клітини розташовуються візуально рідше, ніж у контролі, ядра клітин різко збільшені в розмірах, набряклі, забарвлення помірне і бліде. Звертає на себе увагу розріджене розміщення нейронів (рис. 5).

У кришталику звертала на себе увагу наявність пігментних гранул у товщі його тіла і збільшення числа ядер, розсіяних по периферії. (рис. 6).

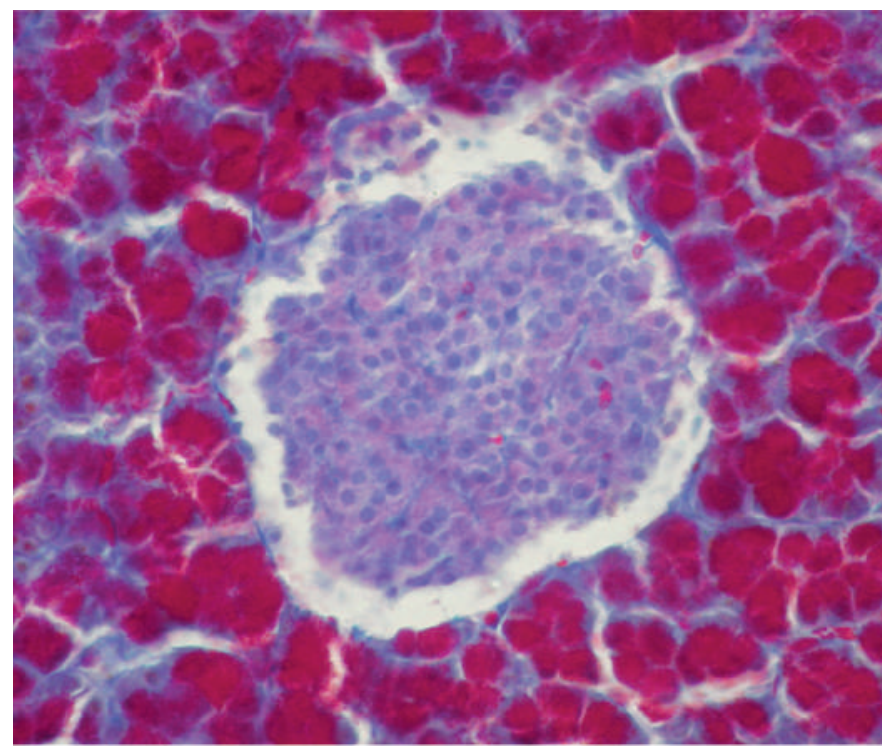

Рис. 1. Група контролю. Фарбування за Маллорі. Зб.: $\times 400$

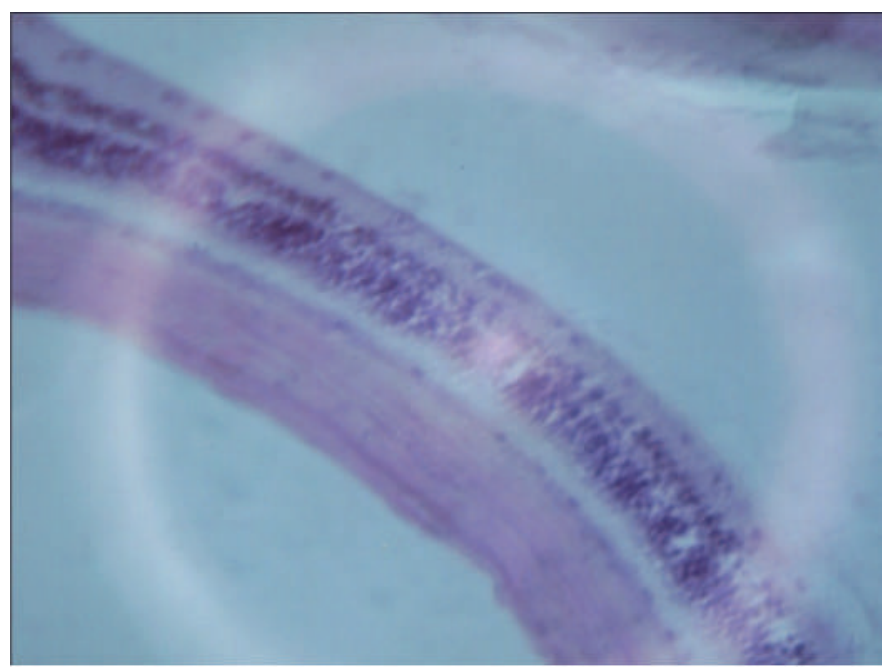

Pис. 2. Сітківка ока здорового щура. Рівномірний розподіл клітин гангліонарного шару. Розділення гранулярних шарів. Фарб.: гематоксилін-еозин. Зб.: × 100

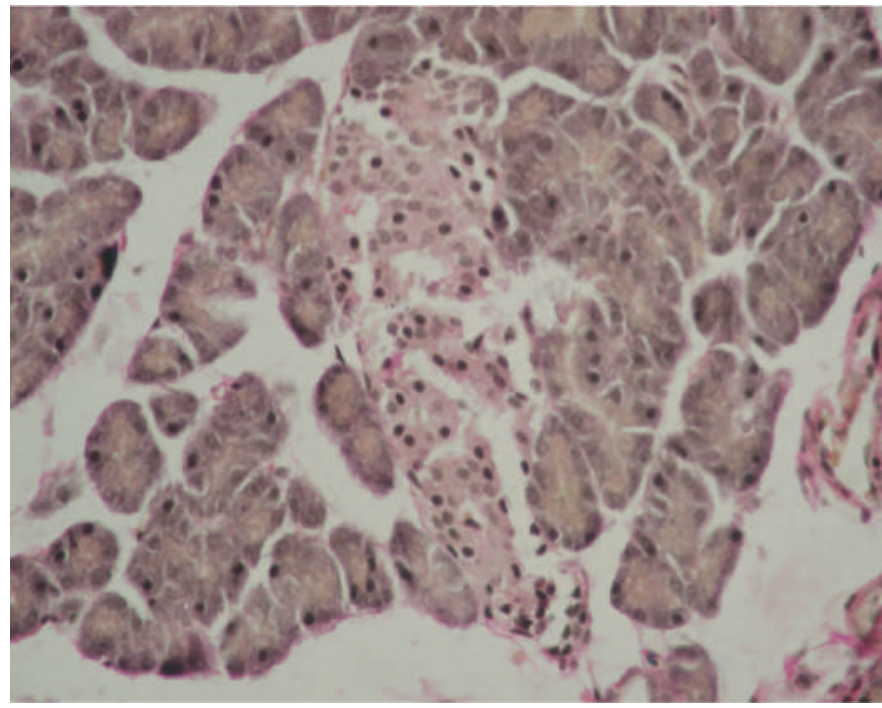

Рис. 3. Тварини 2-ї групи, яким моделювали ЦД 1-го типу. Острівці Лангерганса. Фарбування за Ван Гізоном. Зб.: $\times 400$ 


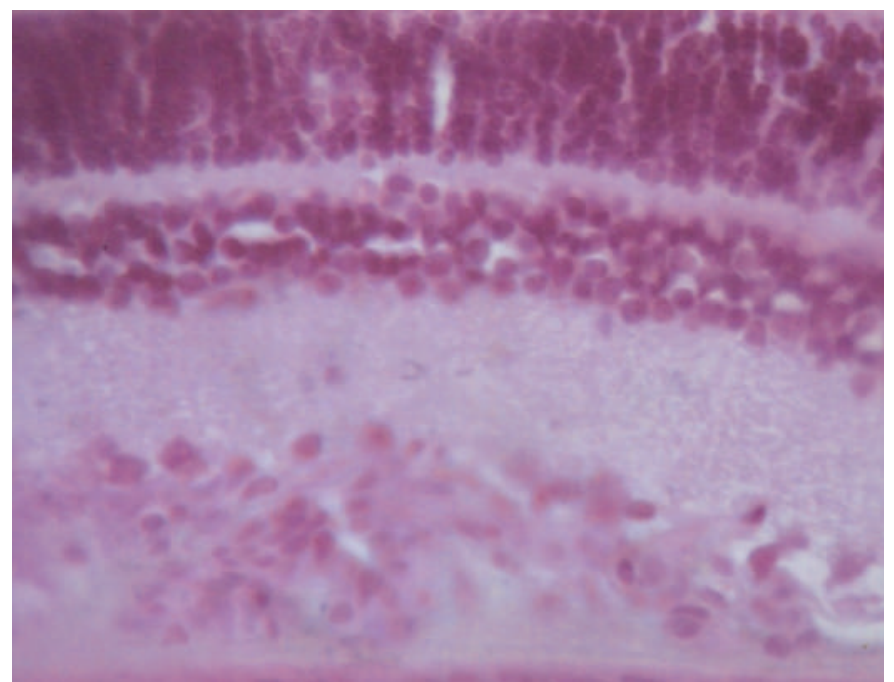

Рис. 4. Сітківка щура з моделлю цукрового діабету. Фарб.: гематоксилін-еозин. Зб.: × 100

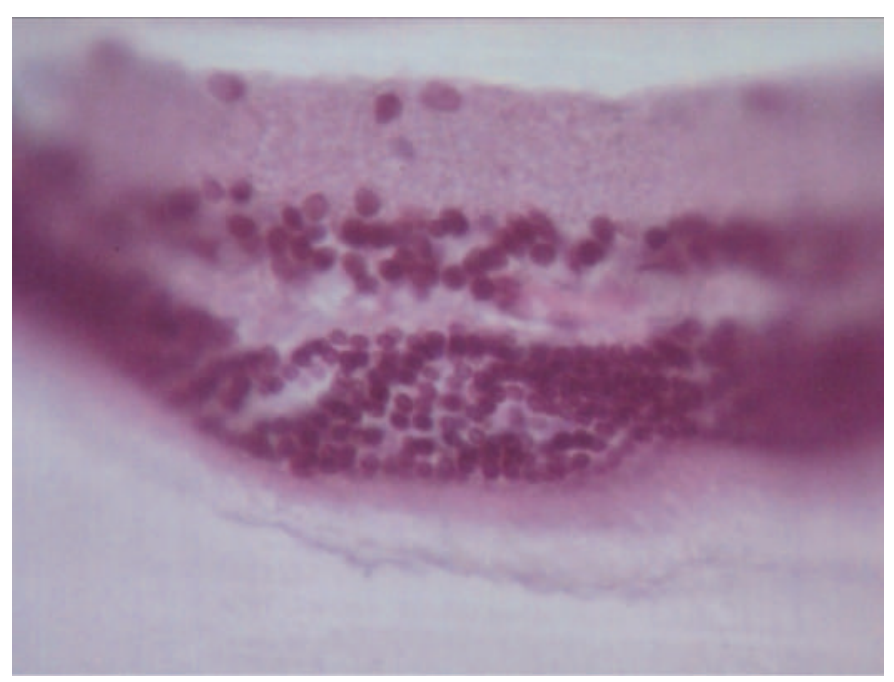

Puc. 5. Сітківка щура з моделлю цукрового діабету. Фарб.: гематоксилін-еозин. Зб.: × 100

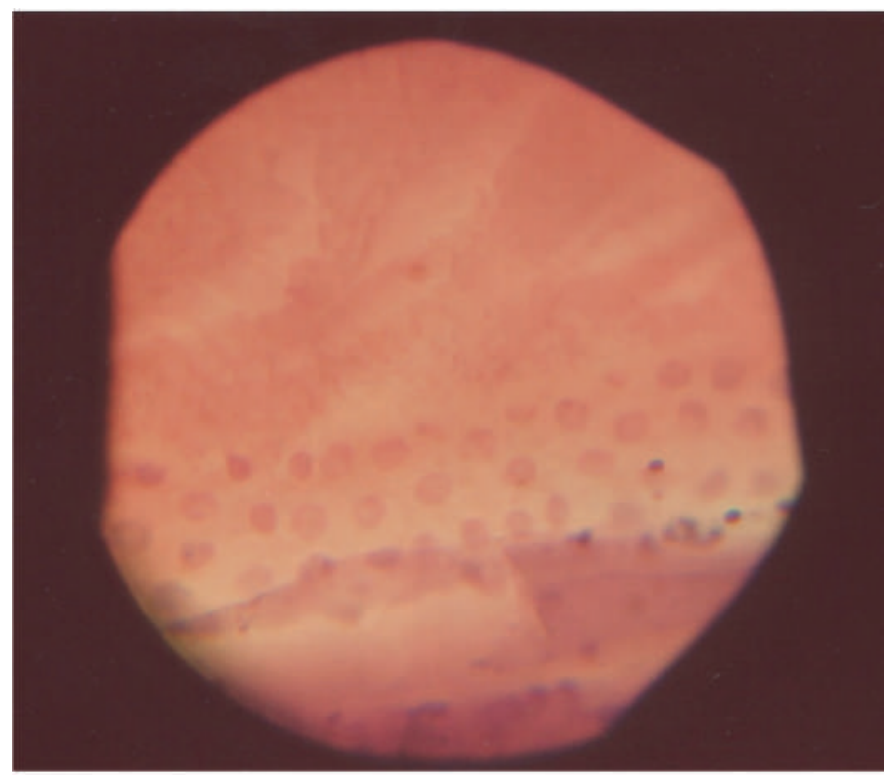

Puc. 6. Кришталик ока щура з моделлю цукрового діабету. Розширення зони вмісту клітини та наявність гранул пігменту. Фарб.: гематоксилін-еозин. Зб.: × 100

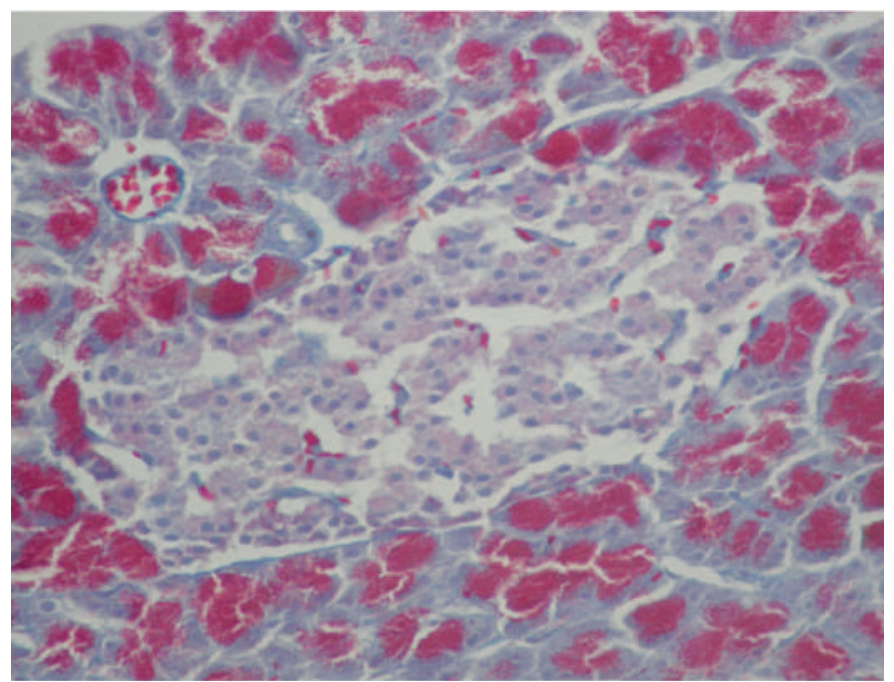

Рис. 7. Тварини 3-ї групи, яким моделювали Цд 2-го типу. Острівці Лангерганса. Фарбування за Маллорі. 3б.: × 400

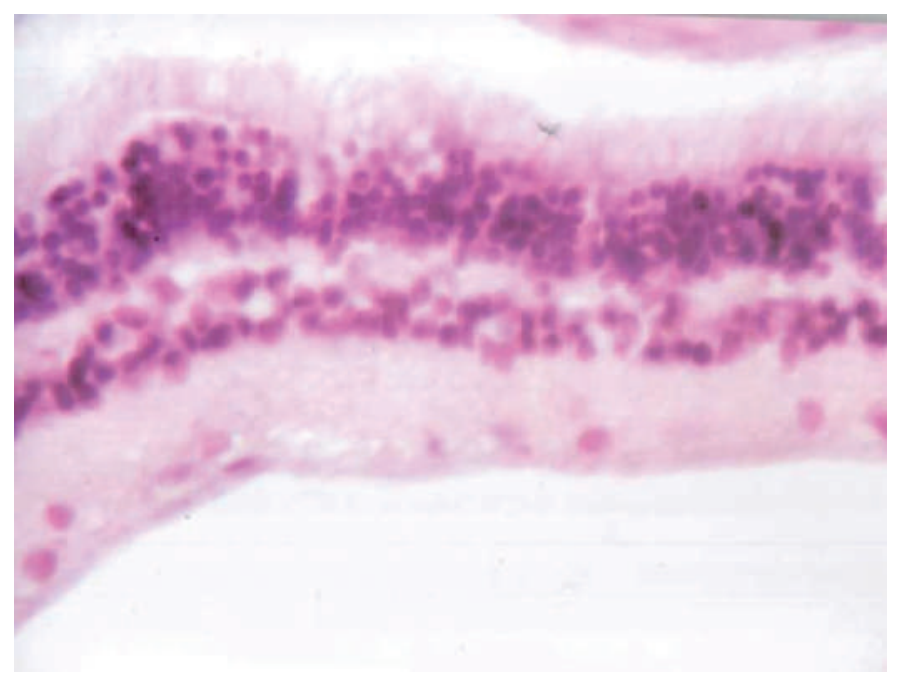

Рис 8. Сітківка щура з моделлю цукрового діабету 2-го типу. Фарб.: гематоксилін-еозин. 3б.: × 100

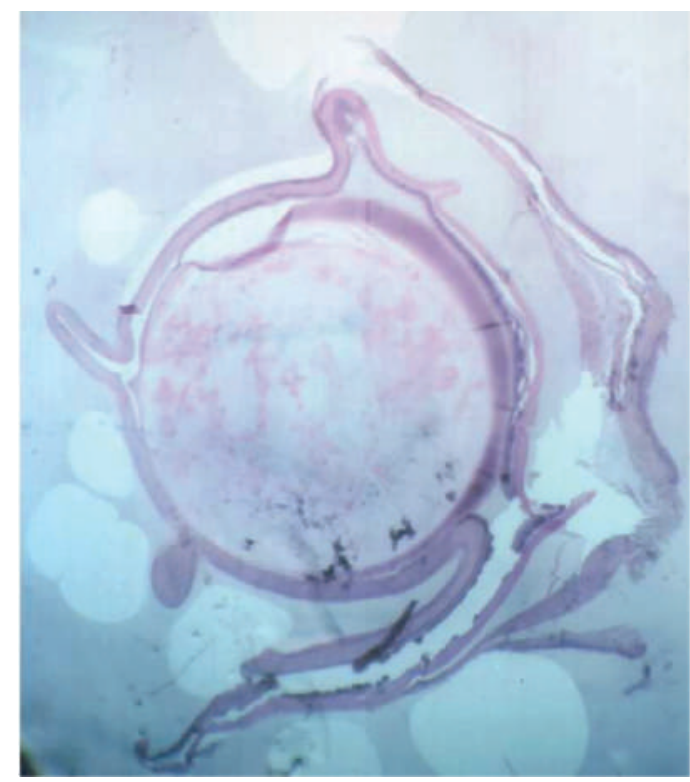

Puс 9. Кришталик ока щура з моделлю цукрового діабету 2-го типу. Фарб.: гематоксилін-еозин. 3б.: × 50 
Результати дослідження 3-ї групи, в якій тваринам моделювали цукровий діабет 2-го типу:

- при дослідженні підшлункової залози виявлено, що кількість $\beta$-клітин дещо зменшена, але при цьому відсутні ознаки руйнування збережених клітин. При аналізі цитоплазми виявлено наявність компенсаторних процесів у збережених клітинах (рис. 7);

- при гістологічному дослідженні структур очного яблука у тварин цієї групи виявлено набухання волокон, неупорядковане розміщення ендотеліоцитів, виявлено їхній набряк. Наявні лакуни. У гангліонарному шарі - розріджене розміщення клітин (рис. 8). У товщі кришталика при дослідженні виявлено пігментні плями (рис. 9).

Як зазначалося вище, вибір алоксанової моделі є обгрунтованим, оскільки механізм дії алоксану - це генерація в циклічній реакції з гіалуроновою кислотою активних форм кисню, котрі ініціюють руйнування $\beta$-клітин. Це відбувається після зв'язування алоксану з транспортером глюкози GLUT2 та вибіркового накопичення в $\beta$-клітинах підшлункової залози експериментальних тварин. Зазначені клітини мають низький рівень антиоксидантного захисту $[8,12]$. Баланс про- та антиоксидантної системи $€$ важливим фактором у патогенезі цукрового діабету.

Використання обох запропонованих нами моделей супроводжувалось 100\%-м виживанням піддослідних щурів. Для моделювання цукрового діабету 1-го типу експериментально була підібрана доза алоксану, котра не призводить до загибелі тварин, але при цьому призводить до деструкції $\beta$-клітин. Використання 5\%го розчину фруктози було додатковим навантаженням на вуглеводний обмін та дезінтегрувало метаболічний процес. Це дозволило нам моделювати цукровий діабет при введенні тваринам менших доз алоксану. Для моделювання цукрового діабету 2-го типу було обрано значно меншу дозу алоксану і при цьому збільшений процент розчину фруктози, що відповідає механізму розвитку цукрового діабету 2-го типу. Як бачимо, за результатами гістологічного дослідження в контрольній групі структура підшлункової залози не зазнала патологічних змін, а в 2-й групі з моделлю ЦД 1-го типу виявлено значне зменшення кількості ендокриноцитів, при цьому в них спостерігаються дегенеративні зміни ядер, що є ознаками дистрофії. У 3-й групі, у якій моделювали цукровий діабет 2-го типу, кількість ендокриноцитів знижена в меншій мірі, відсутні ознаки їх руйнування. При аналізі клітин можна зробити висновок про наявність компенсаторних процесів.

Дослідження змін очного яблука дало змогу виявити, що при змодельованому діабеті 1-го та 2-го типів відбуваються тотожні структурні порушення. В обох групах з експериментальним цукровим діабетом наявні: фіброзне потовщення стінок судин очного яблука, набряк ендотелію, невпорядковане розміщення ендотеліоцитів. Також мали місце дистрофічні зміни клітин гангліонарного шару, що проявилися в розрідженому, в порівнянні з нормою, розміщенні клітин. При цьому в обох експериментальних групах у кришталику звертала на себе увагу наявність пігментних гранул. Вищезазначені зміни, згідно з даними літератури [1], є характерними для розвитку діабетичної ретинопатії.

\section{Висновки}

1. Запропонована алоксанова модель цукрового діабету 1-го типу з додаванням 5\%-го розчину фруктози призводить до значного зменшення кількості $\beta$-клітин, a ті, що збереглися, мають виражені ознаки дистрофії.

2. В ході роботи гістологічно підтверджено ефективність алоксанової моделі цукрового діабету 2-го типу.

3. Виявлено односпрямовану тенденцію пошкодження структур очного яблука при відтворенні обох запропонованих алоксанових моделей експериментального цукрового діабету.

\section{Література}

1. Bum B. B. Патологические изменения сетчатки глаза крыс при экспериментальном сахарном диабете 2-го типа и их коррекция оральными гелями с биологически активными веществами / В. В. Вит, О. Ю. Цисельская, Ю. В. Цисельский, А. П. Левицкий // Офтальмология. - 2013. - Т. 10, № 4. - С. 49-52.

2. Діабет. [Електронний ресурс]: Інформаційний бюлетень ВООЗ. Листопад 2016 р. / Всесвітня організація охорони здоров'я. - Режим доступу: http:// www.who.int/mediacentre/factsheets/fs312/ru/.

3. Зелінська Н. Б. Частота діабетичної ретинопатії у хворих на цукровий діабет дітей та підлітків за даними скринінгу в регіонах України / Н. Б. Зелінська, О. О. Хорошая, Н. А. Старинець // Клінічна ендокринологія та ендокринна хірургія. - 2005. № 4 (13). - C. 27-31.

4. Камышников В. С. Справочник по клинико-биологической лабораторной диагностике / В. С. Камышников - Минск, 2000. - 219 с.

5. Кубатиев А. А. Перекиси липидов и тромбоз/ А. А. Кубатиев, С. В. Андреев // Бюллетень экспериментальной биологии и медицины. - 1979. № 5 - C. 414-417.

6. Маслова О. В. Епідеміологія цукрового діабету та мікросудинних ускладнень / О. В. Маслова, Ю. І. Сунцов // Цукровий діабет. - 2011. - № 3. - С. 6-11.

7. Можейко Л. А. Экспериментальные модели для изучения сахарного диабета / Л. А. Можейко // Журнал Гродненского государственного медицинского университета. - 2013. - № 3. - С.26-29.

8. Пальчикова Н. О. Гормонально-біохімічні особливості аллоксанової та стрептозотоцинової моделей експериментального діабету / Н. О. Пальчикова, Н. В. Кузнецова, О. І. Кузьминова, В. Г. Селятицька // Бюллетень СО РАМН. - 2013. - Т. 33, № 6. - C.18-24. 
9. Паньків В. I. Цукровий діабет: визначення, класифікація, епідеміологія, фактори ризику / В. І. Паньків // Международный эндокринологический журнал. - 2013. - № 7 (55). - С. 95-104.

10. Lee $J . W$. Future applications of antioxidants in premature infants / J. W. Lee, J. M. Davis // Curr. Opin. Pediatr. - 2011. - № 23 (2). - P. 161-166.

11. Li S.Y. Hypoxia-induced oxidative stress in ischemic retinopathy [Електронний ресурс] / S. Y. Li, Z. J. Fu, A. C. Lo// Oxidative Medicine and Cellular Longevity. - 2012. - Режим доступу: https://www.ncbi. nlm.nih.gov/pmc/articles/PMC3483772/.

12. Lenzen $S$. The mechanisms of alloxan- and streptozotocininduced diabetes / S. Lenzen// Diabetologia-2008. - Vol.
51. - P. 216-226. - DOI:10.1007/s00125-007-0886-7.

13. Mathers $C$. D. Projections of global mortality and burden of disease from 2002 to 2030 / C. D. Mathers, D. Loncar // PLoS Med. - 2006. - N 3 (11). - P. 442. - DOI:10.1371/journal.pmed.0030442.

14. Semeraro F. Diabetic retinopathy: vascular and inflammatory disease / F. Semeraro, A. Cancarini, R. dell'Omo [et al.] // Journal of Diabetes Research. 2015. - Vol. 3.-P. 1-17.-DOI:10.1155/2015/582060.

15. Vergouwe $Y$. Progression to microalbuminuria in type 1 diabetes: development and validation of prediction / Y. Vergouwe, S. Soedamah-Muthu, J. Zgibor [et al.] // Diabetologia rule. - 2010. - Vol. 53. - P. 254-262. - DOI:10.1007/s00125-009-1585-3.

\title{
СРАВНИТЕЛЬНАЯ ХАРАКТЕРИСТИКА СТРУКТУРНЫХ ИЗМЕНЕНИЙ ГЛАЗНОГО ЯБЛОКА ПРИ ЭКСПЕРИМЕНТАЛЬНОМ САХАРНОМ ДИАБЕТЕ 1-ГО И 2-ГО ТИПОВ
}

\section{В. В. Семенко, В. Н. Сердюк, И. В. Савиикий}

Диабетическая ретинопатия - грозное осложнение сахарного диабета. Цель работы: проведение сравнительной характеристики изменений глазного яблока при экспериментальной аллоксановой модели сахарного диабета 1-го и 2-го типов. Исследование проведено на белых крысах линии Вистар. Они были разделены на 3 группы. Выявлена тенденция повреждения структур глазного яблока при воспроизведении предложенных аллоксановых моделей экспериментального сахарного диабета 1-го и 2-го типов.

Ключевые слова: сахарный диабет, диабетическая ретинопатия, экспериментальная модель 1-го и 2-го типов, аллоксан, гистологическое исследование.

\section{COMPARATIVE CHARACTERISTICS OF STRUCTURAL CHANGES OF EYE DURING THE EXPERIMENTAL MODEL OF DIABETES MELLITUS TYPES I AND II}

\author{
V.V. Semenko ${ }^{1}$, V. M. Serdyuk ${ }^{1}$, I. V. Savytskyi ${ }^{2}$ \\ ${ }^{1}$ Dnipropetrovsk Regional Clinical Ophthalmologic Hospital \\ Dnipro, Ukraine, \\ ${ }^{2}$ Odesa National Medical University of the Ministry of Public Health of Ukraine \\ Odesa, Ukraine
}

Introduction. Diabetic retinopathy is a dangerous complication of diabetes mellitus (DM), which leads not only to the deterioration of the quality of life, but also to a significant disability of the population.

Goal. To conduct a comparative study of changes in the eyeball under the experimental aloxane model of diabetes mellitus types I and II.

Materials and methods. White rats of the Vistar line weighing 180-200g were used in the study. According to the tasks the animals were ranked into 3 groups: $1^{\text {st }}$ group -20 animals that were not exposed to any of manipulations, served as controls; $2^{\text {nd }}$ group - 30 animals, which simulated diabetes mellitus (DM) type I; $3^{\text {rd }}$ group - 30 animals, which modeled diabetes mellitus type II. The experiment lasted 30 days. Animals were taken from the experiment by decapitation with a light ethereal anesthetic. Histological examination of the pancreas and eyeball structures was performed.

Results. In the control group, the structure of the pancreas was not undergone pathological changes, and in the 2nd group, a significant decrease in the number of endocrinocytes was detected, at the same time in the present endocrinocytes degenerative changes in the nuclei were traced. A number of endocrinocytes was found to be reduced to a lesser degree in 3rd group and there were no signs of destruction. Research of changes in the eyeball made possible to find that identical structural disturbances occur in both types of diabetes mellitus. In both groups with experimental diabetes mellitus there were fibrous thickening of the vascular wall of the eyeball, edema of the endothelium, disordered placement of the endothelial cells. Also there were dystrophic changes in cells of the ganglionic layer. The presence of pigment granules in the lens in both experimental groups attracted attention.

Conclusions: A one-sided tendency of damage of the eyeball structures was revealed while reproducing both proposed aloxane models of experimental diabetes mellitus.

Key words: diabetes mellitus, diabetic retinopathy, experimental model of the $1^{\text {st }}$ and $2^{\text {nd }}$ types, aloxane, histological examination.

Стаття надійшла до редакції 30.07.2018 р. 